\title{
Selective recovery of Streptosporangium fragile from soil by indirect immunomagnetic capture
}

\author{
Paul H. Mullins, ${ }^{1}$ Hanne Gürtler ${ }^{2}$ and Elizabeth $M$. H. Wellington ${ }^{1}$ \\ Author for correspondence: Elizabeth M. H. Wellington. Tel: +44 1203 523184. Fax: +44 1203523701. \\ e-mail: eg@dna.bio.warwick.ac.uk
}

\footnotetext{
1 Department of Biological Sciences, University of Warwick, Coventry CV4 7AL, UK

2 Culture and Metabolite Collection, Novo Nordisk, Bagsvaerd, DK-2880, Denmark
}

\begin{abstract}
A polyclonal antibody raised to Streptosporangium fragile spores reacted strongly and specifically with the immunizing strain and to a number of related species of Streptosporangium, as determined by dot immunoblotting. An indirect immunomagnetic capture method was developed for the recovery of the target organism from sterile and non-sterile soil, using sheep anti-rabbit M-280 Dynabeads. The effects of different soil blocking agents, antibody labelling concentrations and spore/Dynabead capture times on the recovery of S. fragile spores were investigated. Pre-blocking of antibody binding sites within the soil, with either $2 \%$ partially hydrolysed gelatin or $10 \%$ skimmed milk, was essential prior to immunomagnetic capture. Increasing the capture time from 15 to 60 min did not affect spore recovery; however, a 10-fold decline in the magnetic bead concentration did result in a significantly lower recovery of spores from soil. S. fragile was selectively enriched (1:190-fold) when present as a mixed population with Arthrobacter oxydans in sterile soil. The indirect immunomagnetic capture method was used to selectively recover S. fragile spores seeded into non-sterile soil, although some background binding of non-target bacteria was noted. The target was successfully recovered from a sterile soil microcosm after $14 \mathrm{~d}$ incubation and the capture rate was increased by the inclusion of an initial soil dispersion and biomass concentration procedure, using the ion-exchange resin Chelex 100.
\end{abstract}

Keywords: immunocapture, Streptosporangium, soil, magnetic beads, selective isolation

\section{INTRODUCTION}

There is an increasing need to improve methods for the detection and isolation of bacteria from environmental samples, both for the recovery of genetically engineered strains and microbial inoculants (Ford \& Olsen, 1988; Morgan et al., 1989; Pickup, 1991; Trevors et al., 1993) and for the isolation of rare and unusual bacteria for use in industrial screening programmes (Nolan \& Cross, 1988; Shearer, 1987).

Immunomagnetic capture (IMC) represents a potentially important development within this field, allowing the specific recovery of target bacteria from a diverse range of environmental samples. The method relies upon the interaction between cell-surface antigens and antibodies which can be attached to magnetized polystyrene beads.

Abbreviations: DIB, dot immunoblotting; IMC, immunomagnetic capture; MPC, magnetic partlcle concentrator; Non, Nonidet P-40.
Separation of target cells from a suspension can be achieved using a magnetic field. IMC has been widely used in clinical studies for the separation or depletion of target cells from a mixed population (Gaudernack $e t$ al., 1986; Gruhn et al., 1991; Silvestri et al., 1992). More recently it has been used to enrich for and enhance the detection of pathogenic bacteria present in contaminated foodstuffs (Johne et al., 1989; Mansfield et al., 1993; Parmer et al., 1992; Skjerve et al., 1990) and faeces (Luk \& Lindberg, 1991; Tomoyasu, 1992). Work has also focused on the detection and isolation of bacteria by IMC from aquatic environments (Morgan et al., 1991; Christensen $e t$ al., 1992; Bifulco \& Schaefer 1993); however, there has been only one reported study on the use of this method to recover bacteria from the soil environment (Wipat et al., 1994).

Most previous studies have used a direct IMC approach, suitable when monoclonal antibodies are available. However, the value of the method for the isolation of bacteria may be extended by the use of polyclonal antibodies raised 
to many different surface antigens. Such antibodies may avoid the potential problem of high specificity associated with monoclonal antibodies when the isolation of groups rather than individual strains is required. The IMC approach provides a useful alternative to the more traditional selective isolation procedures for the recovery of specific genera of actinomycetes from soil (Hayakawa \& Nonomura, 1989; Wellington \& Toth, 1994). However, there may be problems associated with this method: for example the non-specific binding of antibodies to soil particles, and the separation of cells from soil particles, will be greater than those previously encountered in aquatic and food systems. The study reported here investigated the use of an IMC method for the detection and recovery of bacteria from soil and used, as a model system, the sporogenous soil actinomycete Streptosporangium fragile. This genus was targeted because, unlike the more ubiquitous Streptomyces species, the group is difficult to isolate by traditional culturing methods due to very slow growth on isolation plates and competition from faster-growing actinomycetes.

\section{METHODS}

Bacterial strains. Streptosporangium species were kindly donated by Novo Nordisk. Other actinomycete and bacterial strains used to determine antibody specificity are listed in Table 1.

Isolation of spores. S. fragile was grown on Yeast Starch agar. Spores were harvested (Hopwood et al., 1985), collected by centrifugation at $3000 \mathrm{~g}$ for $10 \mathrm{~min}$ and washed five times with sterile PBS. Spores $\left(1 \times 10^{8}\right.$ c.f.u. $\left.\mathrm{ml}^{-1}\right)$ were either fixed in $4 \%$ $(\mathrm{v} / \mathrm{v})$ formalin, $0 \cdot 15 \mathrm{M}$ sodium chloride (Conway de Macario et al., 1982) and subsequently washed with PBS prior to immunization, or known spore dilutions were prepared in coating buffer $(0.15 \mathrm{M}$ sodium carbonate, $0.35 \mathrm{M}$ sodium hydrogen carbonate; $\mathrm{pH} \mathrm{9.6)}$ for dot immunoblotting. Spores were stored in $20 \%(\mathrm{v} / \mathrm{v})$ glycerol at $-16^{\circ} \mathrm{C}$.

Immunization schedule. Antibodies were raised against the outer spore coat of $S$. fragile in New Zealand White rabbits. Blood was taken at 8 weeks following two weekly booster injections and the IgG fraction purified by ammonium sulphate precipitation and DEAE Sephadex A-50 gel chromatography (Harboe \& Ingild 1983); final protein concentration $5 \mathrm{mg} \mathrm{ml}^{-1}$. Antibody was stored at $4{ }^{\circ} \mathrm{C}$ with $0.01 \%$ thimerosal (Sigma).

Dot immunoblotting (DIB) procedure. Spores and whole cells $\left(10^{7}-10^{8}\right.$ c.f.u. $\left.\mathrm{ml}^{-1}\right)$ were suspended in coating buffer. Sonicated mycelial wall was diluted in coating buffer at $1 \mathrm{mg} \mathrm{ml}^{-1}$ following protein determinations (Bradford, 1976). For S. fragile spores, wall antigen stability after six generations was tested by DIB. Suspensions were blotted onto nitrocellulose membrane filters for DIB (Gordon \& Billing, 1988).

Soil type. Warwick soil was used and prepared as previously described (Wellington et al., 1990). For microcosm studies $S$. fragile spores were seeded into sterile soil amended with $1 \%$ (w/w) crab shell chitin (Sigma) and $1 \%(\mathrm{w} / \mathrm{w})$ soluble starch, wetted to $30 \%(\mathrm{v} / \mathrm{w})$ with distilled water; moisture-holding capacity $80 \%$, matric potential $-5 \mathrm{kPa}$.

Statistical methods. Means were calculated from duplicate or triplicate samples plated in triplicate. Percentage data were subjected to arcsine transformation (Sokal \& Rohlf, 1969), prior to analysis of variance using the MINITAB statistical package (Minitab Statistical Systems). Mean significant difference (MSD) values, at the $95 \%$ confidence level, were calculated from the analysis of variance (Petersen, 1985).

Isolation of target by IMC. Antibody-labelled spores were captured by sheep anti-rabbit (SAR) M-280 Dynabeads (Dynal, UK) and recovered with a magnetic particle concentrator (MPC), product numbers 12002 and 12004 (Dynal, UK). SAR Dynabeads $\left(6-7 \times 10^{8}\right.$ beads $\left.\mathrm{ml}^{-1}, 10 \mathrm{mg} \mathrm{ml}^{-1}\right)$, were washed five times in PBS $/ 0.1 \%(\mathrm{w} / \mathrm{v})$ bovine serum albumin (BSA) fraction V (Sigma) before use as recommended in the manufacturer's instructions. The indirect IMC method was used throughout this study to overcome the problem of non-specific antibodies present within the IgG fraction. Spores were initially labelled with the purified IgG fraction, and unbound and nonspecific antibodies were subsequently removed by centrifugation.

Effect of IMC conditions on the recovery of $S$. fragile from PBS. Spores were added to $1 \mathrm{ml}$ sterile PBS $/ 0 \cdot 1 \%$ BSA $\left(4.0 \times 10^{4}\right.$ c.f.u. $\left.\mathrm{ml}^{-1}\right)$ in $1.5 \mathrm{ml}$ microcentrifuge tubes and were incubated at $20^{\circ} \mathrm{C}$ for $2 \mathrm{~h}$ on a Griffin shaker (speed 6) with $4 \mu \mathrm{l} \mathrm{ml}^{-1}$ of either $S$. fragile antibody or normal rabbit serum. The antibody-labelled spores were then washed three times in fresh PBS $/ 0.05 \%(\mathrm{v} / \mathrm{v}$ ) Nonidet P-40 (Non) buffer and finally resuspended in $1 \mathrm{ml}$ PBS/Non capture buffer. Tubes were gently agitated for $15 \mathrm{~min}$ at room temperature and then placed in the MPC for $3 \mathrm{~min}$. The supernatant, containing uncaptured spores, was removed by pipette and $1 \mathrm{ml}$ fresh PBS/Non was added. One set of tubes was removed from the MPC and the bead/spore complexes were resuspended by hand for $1 \mathrm{~min}$ to remove loosely bound spores. This was designated the first washing step (W1). The bead capture and washing steps were repeated a second (W2) and a third time (W3), when the bead/spore complexes were finally vortex-mixed for $10 \mathrm{~s}$. A second set of tubes was treated as above, but the bead/spore complexes were not resuspended at the first and second washing steps, only at the third step (W3). Viable counts were made at each washing stage. Capture rates were expressed as the percentage recovery of spores remaining after each of the washing steps, relative to the initial spore concentration in the tubes before the addition of the Dynabeads. The effect of different capture buffers and capture times was investigated.

IMC conditions for the recovery of S. fragile from sterile soil. S. fragile spores were mixed into $0.1 \mathrm{~g}$ sterile soil in $1.5 \mathrm{ml}$ microcentrifuge tubes. After $30 \mathrm{~min}$, to allow binding of the spores to the soil, $0.9 \mathrm{ml}$ sterile blocking buffer was added: either PBS $/ 0.05 \%$ (v/v) Non, PBS/Non $/ 10 \%$ (v/v) skimmed milk, or PBS/Non $/ 2 \%(v / v)$ partially hydrolysed (Bohool \& Schmidt, 1968, 1980) gelatin type B (Sigma). The tubes were shaken for $90 \mathrm{~min}$ on a Griffin shaker, before the addition of the specific spore antibody or normal rabbit serum. Tubes were reshaken for $2 \mathrm{~h}$ and non-specific and unbound antibodies were removed by centrifugation at $3000 \mathrm{~g}$ for $10 \mathrm{~min}$. Target spores were recovered using the previously described procedure and spore capture rates at the third washing step were determined. Capture rates were expressed as a percentage of the count obtained by traditional plating method. The effect of antibody concentration at $0 \cdot 2,2 \cdot 0$ and $40 \mu \mathrm{l}(\mathrm{g} \text { soil })^{-1}$ on recovery of $S$. fragile spores seeded into sterile soil was investigated.

Competitive IMC recovery of S. fragile and Arthrobacter oxydans from sterile soil. Microcentrifuge tubes, containing $0 \cdot 1 \mathrm{~g}$ soil, were seeded with either Artbrobacter oxydans JCM 2521 or $S$. fragile, or were co-inoculated with $A$. oxydans and $S$. fragile. The indirect IMC procedure was used. $A$. oxydans was selected for competition to determine the extent of non-specific binding with an unrelated soil bacterium likely to occur under natural conditions. 
IMC of $S$. fragile in non-sterile soil. $S$. fragile spores $\left(4 \cdot 0 \times 10^{5}\right.$ c.f.u. $\left.\mathrm{g}^{-1}\right)$ were inoculated and thoroughly mixed into $0.1 \mathrm{~g}$ non-sterile Warwick soil in $1.5 \mathrm{ml}$ microcentrifuge tubes. After $30 \mathrm{~min}, 0.9 \mathrm{ml}$ sterile PBS/Non $/ 10 \%$ skimmed milk was added. The tubes were shaken for $2 \mathrm{~h}$ at $5{ }^{\circ} \mathrm{C}$ before the addition of $40 \mu \mathrm{g} \mathrm{g}^{-1}$ of spore antibody or normal rabbit serum. S. fragile spores, captured by the indirect IMC procedure, were enumerated before the addition of $30 \mu \mathrm{l}$ Dynabeads $\mathrm{ml}^{-1}$ and after the final third washing step (W3). Appropriate dilutions were plated onto humic-vitamin (HV) medium (Nonomura, 1989) with nystatin $\left(100 \mathrm{mg} \mathrm{l}^{-1} ; \mathrm{BDH}\right)$, with or without gentamicin sulphate $\left(5 \mathrm{mg} \mathrm{l}^{-1}\right.$; Sigma). Putative $S$. fragile colonies were enumerated after $14 \mathrm{~d}$ incubation at $30^{\circ} \mathrm{C}$ and their identity was confirmed phenotypically.

Indirect IMC of S. fragile from soil microcosms. The spore concentration method of Herron \& Wellington (1990) was modified by substituting $0.05 \%(\mathrm{v} / \mathrm{v})$ Non for sodium deoxycholate and polyethylene glycol. Warwick soil $(30 \mathrm{~g})$ was sterilized and inoculated with $S$. fragile spores $\left(3 \cdot 1 \times 10^{5}\right.$ c.f.u. $\left.\mathrm{g}^{-1}\right)$ and after $30 \mathrm{~min}$ a $5 \mathrm{~g}$ sample was suspended in $45 \mathrm{ml} \mathrm{PBS} / \mathrm{Non} / 2 \%$ hydrolysed gelatin and shaken for $2 \mathrm{~h}$ (Griffin shaker). Aliquots of $5 \mathrm{ml}\left(0.5 \mathrm{~g} \mathrm{soil} \mathrm{m}^{-1}\right)$ with $2 \mu \mathrm{g}^{-1}$ spore antibody or normal rabbit serum were used for indirect IMC with 20 or $200 \mu \mathrm{l}$ Dynabeads (g soil $)^{-1}$. A second $5 \mathrm{~g}$ sample was suspended in $15 \mathrm{ml}$ PBS/Non with $1 \mathrm{~g}$ Chelex, shaken for $2 \mathrm{~h}$ and the dispersed soil filtered through a diatomaceous earth filter to remove the resin. The larger soil particles were removed by centrifugation $(1000 \mathrm{~g}, 30 \mathrm{~s})$ and the pellet was re-extracted twice with $5 \mathrm{ml}$ PBS; all supernatants were then pooled and centrifuged at $3000 \mathrm{~g}$ for $20 \mathrm{~min}$. The final pellet was resuspended to $50 \mathrm{ml}$ with PBS/Non/2\% hydrolysed gelatin, stored overnight at $5{ }^{\circ} \mathrm{C}$ and then shaken for $10 \mathrm{~min}$. Aliquots of $5 \mathrm{ml}$ were mixed with spore antibody or rabbit serum $\left[2 \mu \mathrm{l}\left(\mathrm{g}_{\mathrm{g}} \text { soil }\right)^{-1}\right]$ and tubes were shaken for $2 \mathrm{~h}$. SAR Dynabeads, $100 \mu \mathrm{l}$ or $10 \mu \mathrm{l}\left(200\right.$ or $\left.20 \mu \mathrm{g} \mathrm{g}^{-1}\right)$, were added and a capture time of $15 \mathrm{~min}$ used to recover the target spores.

The two IMC recovery methods described above were repeated after $14 \mathrm{~d}$ incubation of the microcosm at $30^{\circ} \mathrm{C}$ and cell capture rates were determined.

\section{RESULTS}

\section{Antibody specificity}

The antibody raised against $S$. fragile spores reacted strongly with spores and sonicated mycelium from the immunizing strain, and moderate cross-reactions to other Streptosporangium species, including $S$. album, $S$. amethystogenes and $S$. violaceochromogenes, were also detected (Table 1). There was no cross-reaction with other Streptosporangium species. Some very weak cross-reactions were noted to sonicated mycelium of Streptomyces species. The $S$. fragile spore antibody showed high levels of reactivity to the target spores even after six sporulation cycles.

\section{Capture conditions for the recovery of target spores from PBS}

There was a clear relationship between the number of washing steps and the proportion of the initial spore population recovered, with the greatest decline noted between the first and second washing steps (Fig. 1). This was anticipated, as the loosely and non-specifically bound spores attached to the Dynabeads were removed. It was probable that the calculated capture rates underestimated the total recovery of target, as more than one spore may have been bound to a Dynabead, but only one colony would have been enumerated. An examination of bead/ spore complexes at the third washing stage by electron microscopy indicated that two to three spores were bound to some beads.

A longer capture time did not significantly increase $(P>$ 0.05 ) spore capture rates (Table 2). Spore recovery increased significantly when PBS/Non was used as the capture and washing buffer. Non-specific attachment of spores to the beads was low $(0 \cdot 1 \%)$ and did not vary significantly with the buffer used. A bead/spore capture time of $15 \mathrm{~min}$ followed by three washing steps, with resuspension between each step, was used throughout the rest of this study.

\section{IMC of S. fragile from sterile soil}

S. fragile spores were recovered from sterile soil using the indirect IMC method with various blocking agents (Table 3). Partially hydrolysed gelatin gave a significantly higher $(P<0.05)$ recovery of spores and was used as the blocking agent in the soil microcosm study. Preliminary studies indicated that 0.1 or $1 \%(\mathrm{w} / \mathrm{v}) \mathrm{BSA} / \mathrm{PBS} / \mathrm{Non}$ and 1 or $10 \%(\mathrm{v} / \mathrm{v})$ normal rabbit serum/PBS/Non did not provide sufficient blocking of the soil for use with the indirect IMC method.

The concentration of the labelling antibody significantly influenced the capture of $S$. fragile spores from soil only at the lowest antibody concentration of $0.2 \mu \mathrm{g}^{-1}$ (data not shown). Comparable results were obtained with hydrolysed gelatin as the blocking agent. $S$. fragile spores were successfully recovered by indirect IMC at the three seeding densities used, with significantly increased $(P<$ $0 \cdot 05)$ capture rates at $10^{3}(40 \cdot 3 \%)$ and $10^{4}$ c.f.u. (g soil $)^{-1}$ $(43.3 \%)$ in comparison to $10^{5}$ c.f.u. $\mathrm{g}^{-1}(26 \cdot 3 \%)$. Background capture rates, using the normal rabbit serum, were low $(<0.05 \%)$ and not significantly $(P>0.05)$ different between treatments.

Selective recovery was achieved from mixtures of $S$. fragile and Artbrobacter oxydans in sterile soil (Table 4). A. oxydans was recovered at very low rates $(0.1 \%)$, using either the spore antibody or normal rabbit serum as the labelling antibody (Table 4). This non-specific binding of cells to the Dynabeads was at a similar level to that observed for S. fragile. The blocking buffer and procedure used did not affect the viability of the Artbrobacter cells. Capture rates of the target were higher in the presence of $A$. oxydans; possibly Artbrobacter cells blocked antibody binding sites within the soil. The results demonstrated the efficiency of the method for the selective recovery of a target organism from a mixed population of cells present in soil.

\section{IMC of S.fragile spores from non-sterile soil}

Recovery of the $S$. fragile spore population from nonsterile soil (data not shown) was $6.1 \%$ (HV-gentamicin) 
Table 1. Specificity of the $S$. fragile spore antibody determined by DIB

Immunoblots were $10 \mu \mathrm{l}$ dots. Antibodies were raised to sonicated mycelium (sm) at $1 \mathrm{mg}$ protein ml $\mathrm{m}^{-1}$ and to spores (sp) at $1 \times 10^{7}$ c.f.u. $\mathrm{ml}^{-1}$ and cells (cl) at $1 \times 10^{8}$ c.f.u. $\mathrm{ml}^{-1}$. Results are from two tests. - , Negative; \pm , weak positive; + , positive; ++ , strongly positive.

\begin{tabular}{|c|c|c|}
\hline Strain & Material & Result \\
\hline Actinomadura pusilla DSM 43357 & sm & - \\
\hline Actinoplanes philippinensis JCM 3001 & $\mathrm{sm}$ & - \\
\hline Amycolatopsis mediterranei NRRL B-3240 & sm & - \\
\hline Artbrobacter oxydans JCM 2521 & $\mathrm{cl}$ & - \\
\hline Bacillus subtilis NCIB 3610 & $\mathrm{cl}$ & - \\
\hline Brevibacterium flavum JCM 1308 & $\mathrm{cl}$ & - \\
\hline Cellulomonas flavigena JCM 1489 & $\mathrm{cl}$ & - \\
\hline Kitasatoa purpurea NRRL B-5403 & sm & - \\
\hline Microbispora rosea JCM 3006 & sm & - \\
\hline Micrococcus luteus A TCC 9341 & $\mathrm{cl}$ & - \\
\hline $\begin{array}{l}\text { Micromonospora ecbinoaurantiaca NRRL } \\
\text { B-16102 }\end{array}$ & sm & - \\
\hline Planobispora rosea JCM 3166 & sm & - \\
\hline Planomonospora parontospora AТCC 23864 & sm & - \\
\hline Planomonospora venezuelensis ATCC 23865 & $\mathrm{sp} / \mathrm{sm}$ & \pm \\
\hline Promicromonospora citrea JCM 3051 & $\mathrm{cl}$ & - \\
\hline Saccbarotbrix aerocolonigenes NRRL B-3298 & $\mathrm{sm}$ & - \\
\hline Streptomyces curacoi ATCC 13385 & $\mathrm{sm}$ & \pm \\
\hline Streptomyces bygroscopicus ATCC 27438 & $\operatorname{sm}$ & - \\
\hline Streptomyces lividans TK 24 & sm & - \\
\hline Streptomyces scabies ATCC 23962 & sp & - \\
\hline Streptomyces violaceus ATCC 15888 & sm & \pm \\
\hline Streptosporangium albidum DSM 43870 & sm & - \\
\hline Streptosporangium album DSM 43023 & sm & + \\
\hline $\begin{array}{l}\text { Streptosporangium amethystogenes } \\
\text { DSM } 43179\end{array}$ & $\mathrm{sm}$ & ++ \\
\hline Streptosporangium corrugatum DSM 43316 & sm & - \\
\hline Streptosporangium fragile DSM 43847 & sm & ++ \\
\hline Streptosporangium fragile DSM 43847 & $\mathrm{sp}$ & ++ \\
\hline $\begin{array}{l}\text { Streptosporangium fragile DSM } 43847 \\
\text { (six sporing cycles) }\end{array}$ & $\mathrm{sp}$ & ++ \\
\hline Streptosporangium longisporum DSM 43180 & $\mathrm{sm}$ & - \\
\hline Streptosporangium roseum DSM 43021 & sm & - \\
\hline Streptosporangium sp. DSM 43137 & $\mathrm{sm}$ & + \\
\hline $\begin{array}{l}\text { Streptosporangium violaceochromogenes } \\
\text { DSM } 43849\end{array}$ & sm & + \\
\hline $\begin{array}{l}\text { Streptosporangium viridogriseum subsp. } \\
\text { viridogriseum DSM } 43850\end{array}$ & $\mathrm{sm}$ & - \\
\hline $\begin{array}{l}\text { Streptosporangium viridogriseum subsp. } \\
\text { viridogriseum DSM } 43850\end{array}$ & sp & - \\
\hline Streptosporangium vulgare DSM 43802 & sm & - \\
\hline Streptoverticillium abikoense NRRL B-1516 & sm & + \\
\hline
\end{tabular}

and $8.3 \%(\mathrm{HV}+$ gentamicin $)$; the difference between these media was not significant (MSD $=3 \cdot 7, P>0 \cdot 05$ ). Background spore capture rates were significantly lower $(P<0.05)$ using the negative control normal rabbit serum as the labelling antibody $(0.2 \% \mathrm{HV}$ - gentamicin, $0 \cdot 1 \%$ $\mathrm{HV}+$ gentamicin). Spore recovery was slightly lower than that from sterile soil in comparable trials (Table 3), possibly due to the interference of other bacteria. A few colonies of streptomycetes were also apparent on the isolation plates.

\section{Soil microcosm studies}

After $14 \mathrm{~d}$ incubation the total population of $S$. fragile increased significantly to day 14 . No significant differences in spore capture rates were detected between the day 0 and 


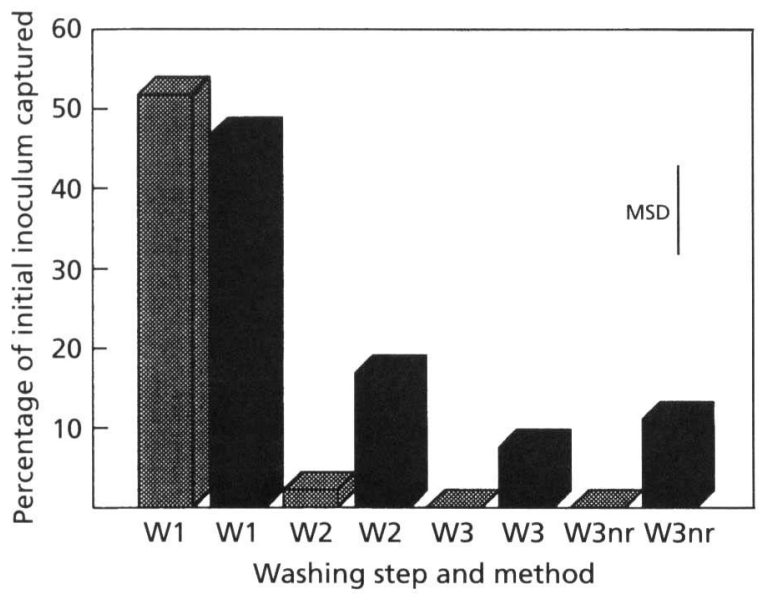

Fig. 1. Effect of washing conditions on the recovery of $S$. fragile spores by IMC from sterile PBS/0.1\% BSA. Percentage recovery of initial spore number $\left(4.0 \times 10^{4}\right.$ c.f.u. $\left.\mathrm{m}^{-1}\right)$ after first (W1), second (W2) and third (W3) washing steps, with or with no resuspension ( $n r)$ of bead/spore complexes, is shown. Antibody/spore labelling time was $120 \mathrm{~min}$, concentration of spore antibody $(\square)$ or normal rabbit serum (E) $4 \mu \mathrm{ml}^{-1}$, capture time $15 \mathrm{~min}$, Dynabeads $10 \mu \mathrm{ml}^{-1}$. Results are means of duplicate samples plated in triplicate. The error bar indicates MSD $(P<0.05)$.

Table 2. Effect of capture buffer and IMC time on the recovery of $S$. fragile spores

IMC time was 15 or $60 \mathrm{~min}$, with $10 \mu \mathrm{l}$ SAR Dynabeads $\mathrm{ml}^{-1}$. Antibody concentration was $4 \mu \mathrm{m} \mathrm{m}^{-1}$ with spore labelling time 120 min in sterile PBS $/ 0.1 \%$ BSA. Results are given as percentage recovery of initial $S$. fragile spore number (trial 1 , $2 \cdot 7 \times 10^{4}$; trial $2,1.8 \times 10^{4}$ c.f.u ml ${ }^{-1}$ ) after the third washing step, using three capture and washing buffers. Results are means of duplicate samples plated in triplicate. $\operatorname{MSD}(P<0.05)$ : trial 1, 3.0; trial $2,5 \cdot 7$.

\begin{tabular}{|c|c|c|c|c|}
\hline \multirow[t]{2}{*}{ Capture buffer } & \multirow{2}{*}{$\begin{array}{c}\text { Trial } \\
\text { no. }\end{array}$} & \multirow{2}{*}{$\begin{array}{c}\text { Capture } \\
\text { time } \\
\text { (min) }\end{array}$} & \multicolumn{2}{|c|}{ Percentage recovery } \\
\hline & & & $\begin{array}{l}\text { Rabbit } \\
\text { serum }\end{array}$ & $\begin{array}{c}\text { Spore } \\
\text { antibody }\end{array}$ \\
\hline PBS & 1 & 15 & $0 \cdot 1$ & $4 \cdot 8$ \\
\hline PBS $/ 0 \cdot 1 \%$ BSA & 1 & 15 & $<0.1$ & $2 \cdot 4$ \\
\hline PBS $/ 0.05 \%$ Non & 1 & 15 & $0 \cdot 1$ & $8 \cdot 3$ \\
\hline PBS $/ 0.05 \%$ Non & 2 & 15 & $0 \cdot 1$ & $9 \cdot 4$ \\
\hline PBS $/ 0.05 \%$ Non & 2 & 60 & $<0.1$ & $7 \cdot 4$ \\
\hline
\end{tabular}

day 14 microcosms using the IMC method without an initial Chelex dispersion step (Fig. 2). The modified Chelex method gave reduced recovery rates in comparison to the standard IMC method at day 0; however, at day 14 the Chelex dispersion step significantly improved $(P<$ 0.05 ) the capture of in situ-grown $S$. fragile: $83 \%$ in comparison to $61 \%$ using the standard IMC method. This may be due to the increased dispersion of the soil particles and target cells, allowing greater access for the labelling antibody and reducing binding of cells to soil particles. A
Table 3. Comparison of blocking agents for IMC of S. fragile spores from sterile soil

Pre-blocking of soil was done for 90 min with partially hydrolysed gelatin or skimmed milk. Rabbit serum (RS) or spore antibody (SA) at $40 \mu \mathrm{l}$ (g soil) ${ }^{-1}$ was used for spore/antibody labelling over $120 \mathrm{~min}$. IMC time was $15 \mathrm{~min}$ with SAR Dynabeads $\left(100 \mu \mathrm{g} \mathrm{g}^{-1}\right)$. The results are percentage capture of initial spore number $\left[5.8 \times 10^{5}\right.$ c.f.u. $\left(\mathrm{g}\right.$ soil) $\left.{ }^{-1}\right]$ after the third washing step; means of two replicates plated in triplicate are shown. MSD $=3.3(P<0.05)$.

\begin{tabular}{|lcc|}
\hline Blocking agent & Antibody & $\begin{array}{c}\text { Percentage } \\
\text { capture }\end{array}$ \\
\hline PBS/Non & RS & $<0.1$ \\
PBS/Non & SA & 0.1 \\
PBS/Non/10\% skim milk & RS & $<0.1$ \\
PBS/Non/10\% skim milk & SA & 10.3 \\
PBS/Non/2\% gelatin & RS & $<0.1$ \\
PBS/Non/2\% gelatin & SA & 15.4 \\
\hline
\end{tabular}

Table 4. Competitive recovery of $S$. fragile from sterile soil co-inoculated with Arthrobacter oxydans

Normal rabbit serum (RS) and spore antibody (SA), each at $2 \mu \mathrm{l}$

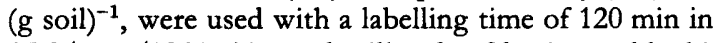
PBS/Non $/ 10 \%$ skimmed milk, after 90 min pre-blocking. IMC

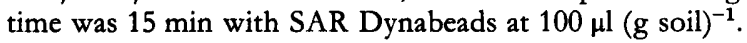
Results are percentage recovery of initial spore or cell number $\left.\left[2.0 \times 10^{5} \text { c.f.u. (g soil }\right)^{-1}\right]$ after the third washing step. Means of duplicate samples plated in triplicate are shown. MSD $(P<0.05)$ : A. oxydans, 0.6; S. fragile, $15 \cdot 0$.

\begin{tabular}{|lcc|}
\hline Species & $\begin{array}{c}\text { Labelling } \\
\text { antibody }\end{array}$ & $\begin{array}{c}\text { Percentage } \\
\text { capture }\end{array}$ \\
\hline A. oxydans & $\mathrm{RS}$ & $0 \cdot 1$ \\
A. oxydans & $\mathrm{SA}$ & $0 \cdot 1$ \\
S. fragile & $\mathrm{RS}$ & $<0 \cdot 1$ \\
S. fragile & $\mathrm{SA}$ & 23.5 \\
A. oxydans* & $\mathrm{SA}$ & $0 \cdot 3$ \\
S. fragile* & $\mathrm{SA}$ & $55 \cdot 8$ \\
\hline
\end{tabular}

* Present as mixed population in soil.

spore/Dynabead ratio of at least 1:100 ensured optimal recovery of target cells.

\section{DISCUSSION}

Initial studies indicated that spore capture rates using a direct IMC procedure were poor (less than $1 \%$ ), although this method has previously proved suitable for use with monoclonal antibodies (Skjerve et al., 1990). This may be due to the low concentration of specific antibodies to the outer spore wall present within a purified IgG fraction, typically between 3 and $30 \%$ (Harboe \& Ingild, 1983). Using an indirect IMC method this problem was overcome by initially labelling the target spores with the IgG 


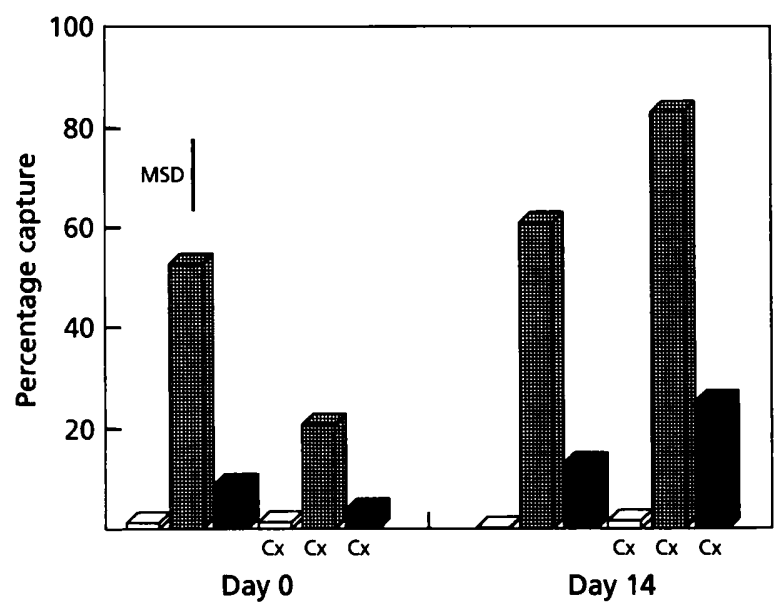

Fig. 2. Effect of Dynabead concentration and a preliminary Chelex $(C x)$ dispersion and spore concentration procedure, on the IMC of $S$. fragile from a sterile soil microcosm at day 0 and day 14. Percentage recovery of initial spore number on day 0 $\left(3.1 \times 10^{5}\right.$ c.f.u. $\left.\mathrm{ml}^{-1}\right)$ and day $14\left(1.2 \times 10^{6}\right.$ c.f.u. $\left.\mathrm{ml}^{-1}\right)$, after the third washing step, is shown. Soil was pre-blocked for $90 \mathrm{~min}$ with $2 \%$ partially hydrolysed gelatin; spore antibody or rabbit serum labelling time was 120 min, concentration $2 \mu \mathrm{l}$ (g soil) $)^{-1}$, capture time 15 min, Dynabeads, 200 or $20 \mu \mathrm{l}$ (g soil) ${ }^{-1}$. Results are means of triplicate samples, plated in triplicate. The error bar indicates MSD $(P<0.05)$. $\square$, Rabbit serum, $200 \mu$ l Dynabeads (g soil) $)^{-1}$; 曲, spore antibody, $200 \mu l$ Dynabeads (g soil) ${ }^{-1}$;, spore antibody, $20 \mu$ l Dynabeads (g soil) ${ }^{-1}$.

fraction and then removing non-specific and unbound antibodies during subsequent centrifugation steps. This indirect approach was successfully developed for the recovery of $S$. fragile spores from buffer solutions and from sterile and non-sterile soil.

IMC recovery rates for $S$. fragile spores from soil varied between 5 and $80 \%$, but were usually in the range of $10-20 \%$ of the count obtained by traditional plating. Whilst selective plating allowed more efficient recovery, the capture method produced cleaner isolation plates, which in many soils would greatly increase the successful isolation of slow-growing genera. Recovery of $S$. fragile spores was significantly higher at low population densities, indicating that the method would be suitable for the isolation of target bacteria present at low population densities in soil. Comparable recovery rates were reported for the IMC of bacterial cells both from aquatic environments (Bifulco \& Schaefer, 1993; Morgan et al., 1991) and from a variety of dairy and meat products (Fratamico et al., 1992; Lund et al., 1988; Skjerve et al., 1990; Vermunt et al., 1992). However, Skjerve \& Olsvik (1991) noted that the IMC method was not suitable for use with certain foodstuffs, including yoghurt, due to the presence of high levels of indigenous microflora.

Increasing the spore/bead capture time did not improve the recovery rate of spores, supporting the observations of Blackburn et al. (1991), who found that the greatest immunobinding of Salmonella to Dynabeads occurred within the first few minutes, with near maximal levels after $15 \mathrm{~min}$. Increased capture time was always associated with greater non-specific binding of bacterial cells to the magnetic beads (Fratamico et al., 1992; Morgan et al., 1991). This increase in the level of non-specific binding was not observed during this study.

The ratio of magnetic beads to target spores significantly influenced the capture of $S$. fragile spores. Morgan et al. (1991) found that an increase in the cell/bead ratio from 10:1 to $10000: 1$ did not markedly affect the recovery of Pseudomonas cells from lake water. A high cell/bead ratio is suitable for studies with soil due to binding of cells to soil particles and reduced mixing. In this study, nonspecific binding of antibody to soil particles was reduced by use of gelatin as a blocking agent; this technique has been used for immunofluorescence studies of soil for Rbizobium (Bohool \& Schmidt, 1980; Postama et al., 1988; Schmidt, 1974) and Salmonella (Turpin et al., 1993a). The use of the gelatin block also reduced the compaction of the soil after centrifugation, allowing greater dispersion of the soil particles during the resuspension steps required in the indirect IMC method. The nature of the washing conditions used significantly affected the proportion of target cells recovered, confirming the findings of others (Blackburn et al., 1991; Lund et al., 1988, Morgan et al., 1991)

The enrichment ratio of $1: 190$ obtained for target spores from mixed cultures in soil was similar to that reported by Lund et al. (1988) for Escherichia coli (>190-fold) and Blackburn et al. (1991) for the enrichment of Salmonella from four different bacteria (3- to $>2700$-fold). The inclusion of a detergent in the washing and capture buffer improved the dispersion of target cells from the soil particles, facilitating capture of the bead/spore complexes. No detrimental effects of exposure to detergent were noted, in contrast to other studies (Morgan et al., 1991). Further chemical disruption of the soil using the ion-exchange resin Chelex 100, in a preliminary spore dispersion and concentration step (Herron \& Wellington 1990; Turpin et al., 1993b), resulted in an increased recovery of in situ-grown cells from the day 14 soil microcosm. No effect was seen at day 0 as the spores seeded into the soil were not tightly bound to, or entrapped within, the soil matrix.

No decline in antibody reactivity to the spores was detected. Previous studies have reported that epitope stability in soil is maintained at least over several cell cycles, or for a few months (Mason \& Burns, 1990; Kinkle \& Schmidt, 1992). However, Wipat et al. (1992) noted a slight decline in the reactivity of Streptomyces lividans spores after 14 weeks incubation in soil, probably as a result of lower levels of antigen expression or accessibility. Variations in the expression of surface antigens, in response to growth conditions, have been reported in Gram-negative bacteria (Nelson et al., 1991).

In conclusion, an indirect IMC method was developed for the recovery of a high proportion of the $S$. fragile spores present in both sterile and non-sterile soil. This method was shown to be suitable for the recovery of in situ-grown cells and, when used in conjunction with an initial Chelex dispersion step, resulted in the capture of up to $83 \%$ of 
the spore population present in the soil, within a concentrated bead/spore pellet that was substantially free from contaminating soil particles. Spores produced in the soil were equally reactive but more tightly bound to soil particles. Further studies will investigate the distribution of spores in soil and determine their physiological status.

\section{ACKNOWLEDGEMENTS}

We gratefully acknowledge the financial support of Novo Nordisk A/S. We wish to thank Annette Petersen for raising and purifying the antibody, and Paul Baker for technical assistance.

\section{REFERENCES}

Bifulco, J. M. \& Schaefer, F. W. (1993). Antibody-magnetite method for the selective concentration of Giardia lamblia cysts from water samples. Appl Environ Microbiol 59, 772-776.

Blackburn, C. de W., Patel, P. D. \& Gibbs, P. A. (1991). Separation and detection of Salmonellae using immunomagnetic particles. Biofouling 5, 143-156.

Bohool, B. B. \& Schmidt, E. L. (1980). The immunofluorescence approach in microbial ecology. Adv Microb Ecol 4, 203-241.

Bradford, M. M. (1976). A rapid and sensitive method for the quantitation of microgram quantities of protein utilizing the principle of protein-dye binding. Anal Biochem 72, 248-254.

Christensen, B., Torsvik, T. \& Lien, T. (1992). Immunomagnetically captured thermophilic sulphate-reducing bacteria from North Sea oil field waters. Appl Environ Microbiol 58, 1244-1248.

Conway de Macario, E., Wolin, M. J. \& Macario, A. J. L. (1982). Specific antisera and immunological procedures for characterization of methanogenic bacteria. J Bacteriol 149, 320-328.

Ford, S. F. \& Olsen, B. (1988). Methods for detecting genetically engineered microorganisms in the environment. Adv Microb Ecol $10,45-79$.

Fratamico, P. M., Schultz, F. J. \& Buchanan, R. L. (1992). Rapid isolation of Escherichia coli $\mathrm{O} 157: \mathrm{H} 7$ from enrichment cultures of foods using an immunomagnetic separation method. Food Microbiol 9, 105-113.

Gaudernack, G., Ugelstad, T. \& Thoresby, E. (1986). Isolation of pure functionally active $\mathrm{CD}^{+} \mathrm{T}$ cells. Positive selection with monoclonal antibodies directly conjugated to monosized magnetic microspheres. J Immunol Meth 90, 179-187.

Gordon, J. \& Billing, P. (1988). Dot immunobinding, general principles and procedures. In CRC Handbook of Immunoblotting of Proteins, vol. 1, section 2, pp. 27-30. Edited by O. J. Bjerrum \& N. H. H. Heegaard. Boca Raton, Florida: CRC Press.

Gruhn, B. R., Haefer, A., Mueller, W., Andrae, H., Danan \& Zintl, F. (1991). Model experiments for immunomagnetic elimination of leukemic cells from human bone marrow: presentation of a novel magnetic separation system. Immunobiology 183, 374-385.

Harboe, N. M. G. \& Ingild, A. (1983). Immunization, isolation of immunoglobulins and antibody titre determination. Scand J Immunol 17, 345-351.

Hayakawa, M. \& Nonomura, H. (1989). A new method for the intensive isolation of actinomycetes from soil. Actinomycetologica 3, 95-104.

Herron, P. R. \& Wellington, E. M. H. (1990). New method for extraction of streptomycete spores from soil and application to the study of lysogeny in sterile amended and nonsterile soil. Appl Environ Microbiol 56, 1406-1412.
Hopwood, D. A., Bibb, M. J., Chater, K. F., Kieser, T., Bruton, C. J., Kieser, M., Lydiate, D. J., Smith, C. P., Ward, J. M. \& Schrempf, H. (1985). In Genetic Manipulation of Streptomyces: a Laboratory Manual, pp. 3-5. Norwich: John Innes Foundation.

Johne, B., Jarp, J. \& Haaheim, L. R. (1992). Staphylococcus aureus exopolysaccharide in vivo demonstrated by immunomagnetic separation and electron microscopy. J Clin Microbiol 27, 1631-1635.

Luk, J. M. C. \& Lindberg, A. A. (1991). Rapid and sensitive detection of Salmonella $(\mathrm{O}: 67)$ by immunomagnetic monoclonal antibodybased assays. J Immunol Meth 137, 1-8.

Lund, A., Helleman, A. L. \& Vartdal, F. (1988). Rapid isolation of $\mathrm{K}^{+} 8^{+}$Escherichia coli by using immunomagnetic particles. J Clin Microbiol 26, 2572-2575.

Mansfield, L. P. \& Forsythe, S. J. (1993). Immunomagnetic separation as an alternative to enrichment broths for Salmonella detection. Lett Appl Microbiol 16, 122-125.

Mason, J. \& Burns, R. G. (1990). Production of a monoclonal antibody specific for a Flavobacterium species isolated from soil. FEMS Microbiol Ecol 73, 299-308.

Morgan, J. A. W., Winstanley, C., Pickup, R. W., Jones, J. G. \& Saunders, J. R. (1989). Direct phenotypic and genotypic detection of a recombinant pseudomonad population released into lake water. Appl Environ Microbiol 55, 2537-2544.

Morgan, J. A. W., Winstanley, C., Pickup, R. W. \& Saunders, J. R. (1991). Rapid immunomagnetic capture of $P$ seudomonas putida cells from lake water by using bacterial flagella. Appl Environ Microbiol 57, 503-509.

Nelson, D., Bathgate, A. J. \& Poxton, I. R. (1991). Monoclonal antibodies as probes for detecting lipopolysaccharide expression on Eschericbia coli from different growth conditions. J Gen Microbiol 137, 2741-2751.

Nolan, R. D. \& Cross, T. (1988). Isolation and screening of actinomycetes. In Actinomycetes in Biotechnology, pp. 1-32. Edited by M. Goodfellow, S. T. Williams \& M. Mordarski. London: Academic Press.

Nonomura, H. (1989). Genus Streptosporangium Couch 1955. In Bergey's Manual of Systematic Bacteriology, vol. 4, pp. 2545-2551. Edited by S. T. Williams, M. Sharpe \& J. G. Holt. Baltimore: Williams \& Wilkins.

Parmer, N., Easter, M. C. \& Forsythe, S. J. (1992). The detection of Salmonella enteritidis and $S$. typhimurium using immunomagnetic separation and conductance microbiology. Lett Appl Microbiol 15, 175-178.

Petersen, R. G. (1985). Separation of means. In Design and Analysis of Experiments (Statistics: Textbooks and Monographs vol. 66), pp. 72-111. New York: Marcel-Dekker.

Pickup, R. W. (1991). Development of molecular methods for the detection of specific bacteria in the environment. $J$ Gen Microbiol 137, 1009-1019.

Postma, J., van Elsas, J. D., Govaert, J. M \& Veen, J. A. (1988). The dynamics of Rhizobium leguminosarum biovar trifolii introduced into soil as determined by immunofluorescence and selective plating techniques. FEMS Microbiol Ecol 53, 251-260.

Schmidt, E. L. (1974). Quantitative autecological study of microorganisms in soil by immunofluorecsence. Soil Sci 118, 141-149.

Shearer, M. C. (1987). Methods for the isolation of nonstreptomycete actinomycetes. Developments in industrial microbiology J Ind Microbiol 28, Suppl. 2, 91-97. Edited by G. Pierce.

Silvestri, F., Banavali, S., Yin, M., Gopal, V., Savignano, C., Baccarani, M. \& Preisler, H. D. (1992). CD34-positive cell selection by immunomagnetic beads and chymopapain. Haematologica $\mathbf{7 7}$, 307-310. 
Skjerve, E. \& Olsvik, O. (1991). Immunomagnetic separation of Salmonella from foods. Int J Food Microbiol 14, 11-18.

Skjerve, E., Rorvik, L. M. \& Olsvik, O. (1990). Detection of Listeria monocytogenes in foods by immunomagnetic separation. Appl Environ Microbiol 56, 3478-3481.

Sokal, R. R. \& Rohlf, F. J. (1969). Assumptions of ANOv. In Biometry: Principles and Practice of Statistics in Biological Research, pp. 235-246. San Francisco: W. H. Freeman.

Tomoyasu, T. (1992). Development of the immunomagnetic enrichment method selective for Vibrio parabaemolyticus serotype $\mathrm{K}$ and its application to a food poisoning study. Appl Environ Microbiol 58, 2679-2682.

Trevors, J. T., Van Elsas, J. D., Lee, H. \& Wolters, A. C. (1993). Survival of alginate-encapsulated Pseudomonas fuorescens cells in soil. Appl Microbiol Biotechnol 39, 637-643.

Turpin, P. E., Maycroft, K. A., Rowlands, C. L. \& Wellington, E. M. H. (1993a). Viable but non-culturable salmonellas in soil. $J$ Appl Bacteriol 74, 421-427.

Turpin, P. E., Maycroft, K. A., Rowlands, C. L. \& Wellington,
E. M. H. (1993b). An ion-exchange based extraction method for the detection of salmonellas in soil. J Appl Bacteriol 74, 181-190.

Vermunt, A. E. M., Franken, A. A. J. M. \& Beumer, R. R. (1992). Isolation of salmonellas by immunomagnetic separation. $J A p p l$ Bacteriol 72, 112-118.

Wellington, E. M. H. \& Toth, I. K. (1994). Actinomycetes. In Methods of Soil Analysis: part 2, Microbiological and Biochemical Properties of Soils, 3rd edn, pp. 269-290. Edited by R. W. Weaver, J. S. Angle \& P. S. Bottomly. Madison, WI: Soil Science Society of America.

Wellington, E. M. H., Cresswell, N. C. \& Saunders, V. A. (1990). Growth and survival of streptomycete inoculants and extent of plasmid transfer in sterile and nonsterile soil. Appl Environ Microbiol 56, 1413-1419.

Wipat A., Wellington, E. M. H. \& Saunders, V. A. (1994). Immunological detection and recovery of genetically manipulated streptomycetes from soil. Microbiology 140, 2067-2076.

Received 10 March 1995; revised 23 May 1995; accepted 25 May 1995. 